Article

\title{
Impacts of Carbon Dioxide Enrichment on Landrace and Released Ethiopian Barley (Hordeum vulgare L.) Cultivars
}

\author{
Mekides Woldegiorgis Gardi ${ }^{1}{ }^{*}$, Waqas Ahmed Malik ${ }^{2}$ and Bettina I. G. Haussmann ${ }^{3}$ (D) \\ 1 Institute of Cropping Systems and Modelling, University of Hohenheim, Fruwirthstrasse 14, 70599 Stuttgart, \\ Germany \\ 2 Institute of Biostatistics, University of Hohenheim, 70599 Stuttgart, Germany; W.Malik@uni-hohenheim.de \\ 3 Institute of Plant Breeding, Seed Science and Population Genetics, University of Hohenheim, 70599 Stuttgart, \\ Germany; bettina.haussmann@uni-hohenheim.de \\ * Correspondence: mekides.gardi@uni-hohenheim.de; Tel.: +49-17-7773-4262
}

Citation: Gardi, M.W.; Malik, W.A.; Haussmann, B.I.G. Impacts of Carbon Dioxide Enrichment on Landrace and Released Ethiopian Barley (Hordeum vulgare L.) Cultivars. Plants 2021, 10 , 2691. https://doi.org/10.3390/ plants10122691

Academic Editor: James Bunce

Received: 20 November 2021 Accepted: 4 December 2021

Published: 7 December 2021

Publisher's Note: MDPI stays neutral with regard to jurisdictional claims in published maps and institutional affiliations.

Copyright: (C) 2021 by the authors. Licensee MDPI, Basel, Switzerland. This article is an open access article distributed under the terms and conditions of the Creative Commons Attribution (CC BY) license (https:/ / creativecommons.org/licenses/by/ $4.0 /)$.

\begin{abstract}
Barley (Hordeum vulgare L.) is an important food security crop due to its high-stress tolerance. This study explored the effects of $\mathrm{CO}_{2}$ enrichment $\left(\mathrm{eCO}_{2}\right)$ on the growth, yield, and water-use efficiency of Ethiopian barley cultivars (15 landraces, 15 released). Cultivars were grown under two levels of $\mathrm{CO}_{2}$ concentration (400 and $550 \mathrm{ppm}$ ) in climate chambers, and each level was replicated three times. A significant positive effect of $\mathrm{eCO}_{2}$ enrichment was observed on plant height by 9.5 and $6.7 \%$, vegetative biomass by 7.6 and $9.4 \%$, and grain yield by 34.1 and $40.6 \%$ in landraces and released cultivars, respectively. The observed increment of grain yield mainly resulted from the significant positive effect of $\mathrm{eCO}_{2}$ on grain number per plant. The water-use efficiency of vegetative biomass and grain yield significantly increased by 7.9 and $33.3 \%$ in landraces, with 9.5 and $42.9 \%$ improvement in released cultivars, respectively. Pearson's correlation analysis revealed positive relationships between grain yield and grain number $(r=0.95)$, harvest index $(r=0.86)$, and ear biomass $(r=0.85)$. The response of barley to $\mathrm{eCO}_{2}$ was cultivar dependent, i.e., the highest grain yield response to $\mathrm{eCO}_{2}$ was observed for Lan_15 (122.3\%) and Rel_10 (140.2\%). However, Lan_13, Land_14, and Rel_3 showed reduced grain yield by 16,25 , and $42 \%$, respectively, in response to eCO enrichment. While the released cultivars benefited more from higher levels of $\mathrm{CO}_{2}$ in relative terms, some landraces displayed better actual values. Under future climate conditions, i.e., future $\mathrm{CO}_{2}$ concentrations, grain yield production could benefit from the promotion of landrace and released cultivars with higher grain numbers and higher levels of water-use efficiency of the grain. The superior cultivars that were identified in the present study represent valuable genetic resources for future barley breeding.
\end{abstract}

Keywords: barley; biomass; $\mathrm{CO}_{2}$ enrichment; Hordeum vulgare L.; water-use efficiency; yield

\section{Introduction}

The global demand for food crops is increasing and may continue to do so for decades. A $70-100 \%$ increase in the cereal food supply by 2050 is required to feed the predicted world population of over nine billion people [1]. In terms of production and consumption, barley (Hordeum vulgare L.) is one of the most important cereal crops in the world following wheat, maize, and rice. It is cultivated both in highly productive agricultural systems and at the subsistence level in marginal environments [2]. Ethiopia is the second-largest barley producer in Africa, accounting for nearly $25 \%$ of the total production [3]. It has been cultivated in Ethiopia for the last 5000 years and accounts for $8 \%$ of the total cereal production in the country [4]. In the $2017 / 18$ growing season, the national area coverage was 975,300 ha, with the production and productivity values of barley being approximately 2.1 million tons and 2.17 tons $\mathrm{ha}^{-1}$, respectively [3]. It is grown at elevations from 1500 to over $3500 \mathrm{~m}$ above sea level (m.a.s.l) and is predominantly cultivated between 2000 and 3000 m.a.s.1. $[5,6]$. 
Ethiopian barley germplasm has been used internationally as a source of useful genes due to its improved traits, including improved protein quality and disease and drought tolerance [5,7]. Long-term geographic isolation and adaptation to diverse climatic conditions and soil types resulted in a high level of variation between cultivars [8]. The crop is primarily used as a type of food and beverage in more than 20 different ways, which reflects its cultural and nutritional importance [9]. Despite its importance and morphological variations, one key challenge in barley breeding is the issue of developing cultivars that can face the challenges of changing climatic conditions [10]. Changes in the global atmospheric $\mathrm{CO}_{2}$ concentration constitute one of the most important and wellknown examples of global climate change. The current increase in $\mathrm{CO}_{2}$ will likely continue into future decades and may bring the concentration close to $550 \mathrm{ppm}$ by 2050 [11,12]. Elevated $\mathrm{CO}_{2}\left(\mathrm{eCO}_{2}\right)$ levels are known to have positive effects on photosynthetic processes, and consequently, on plant growth in $\mathrm{C} 3$ plant species, mainly through the modification of water and nutrient turnover [13-15]. Thus, as $\mathrm{CO}_{2}$ is fundamental for plant production, understanding cultivar behavior and the targeted exploitation of this resource via plant breeding could optimize yields and contribute to future food security [16-18].

Several $\mathrm{CO}_{2}$-enrichment studies regarding major cereal species, i.e., barley [19-21], wheat [22,23], and rice [24], reported substantial intraspecific variation between cultivars regarding plant growth and yield in response to $\mathrm{eCO}_{2}$ enrichment. In contrast, another study regarding different cultivars of wheat reported non-significant intraspecific variation in yield responses [25]. To the best of our knowledge, no information is currently available regarding the response of Ethiopian barley cultivars to $\mathrm{eCO}_{2}$. Therefore, the present study aimed to evaluate the growth, yield formation, and water-use efficiency response of Ethiopian barley cultivars under current and future $\mathrm{CO}_{2}$ concentrations.

\section{Results}

\subsection{Plant Height and Biomass Allocation Pattern}

Significant impacts caused by $\mathrm{CO}_{2}$ enrichment were observed for several yield variables in both the landrace and released cultivars, except in the variables of leaf biomass fraction, the number of ears per plant, and thousand-grain weight. The interaction between $\mathrm{CO}_{2}$ and the cultivars also had a significant effect on most of the yield variables (Table 1). The average plant height of the landrace and released cultivars in the ambient $\mathrm{CO}_{2}\left(\mathrm{aCO}_{2}\right)$ condition were 101.9 and $94.5 \mathrm{~cm}$, respectively (Table 1 ). The effect of $\mathrm{CO}_{2}$ enrichment was observed in the variable of plant height, with an increase of $7.6 \%$ in landraces and $6.7 \%$ in released cultivars (Figure 1). The average vegetative biomass of the landrace was $35.6 \mathrm{~g}$ dry weight per plant in the $\mathrm{aCO}_{2}$ condition (Table 1), while the released cultivars had $39.4 \mathrm{~g}$ dry weight per plant (Table 1). Significant increases in vegetative biomass, by 7.6 and $9.4 \%$, respectively, were recorded across the landrace and released cultivars in the $\mathrm{eCO}_{2}$ condition (Figure 1). The increase observed in vegetative biomass was mainly due to the significant effect of $\mathrm{eCO}_{2}$ on the stem biomass in both the landrace and released cultivars (Table 1). As shown in Figure 2, a negative correlation between vegetative biomass and grain yield $(r=-0.51, p<0.05)$ as well as harvest index $(r=-0.85, p<0.001)$ was observed.

\subsection{Grain Yield Parameters}

Grain yield and its parameters were significantly affected by genotype/cultivars, $\mathrm{CO}_{2}$ treatment, and their interaction in both the landrace and released cultivars (Table 1). The average grain yield of the landrace was $8.1 \mathrm{~g}$ dry weight per plant, resulting from 13.8 ears and 146 grains per plant. On the other hand, the released cultivars had a grain yield of $6.7 \mathrm{~g}$ dry weight per plant from 12.8 ears and 134 grains per plant, on average, under the $\mathrm{aCO}_{2}$ conditions. Increases in the grain yield of the landrace and released cultivars, by 34.1 and $40.6 \%$, respectively, were recorded under the $\mathrm{eCO}_{2}$ condition (Table 1 and Figure 1). All yield components contributed significantly to the increase in grain yield, except for the number of ears. The number of grains per plant showed the largest increase of $32.2 \%$ in the landrace and $31.3 \%$ in the released cultivars (Table 1 and Figure 1). In accordance 
with this, the harvest index increased by $14.3 \%$ (landraces) and $23.3 \%$ (released cultivars) in the $\mathrm{eCO}_{2}$ condition. The $\mathrm{eCO}_{2}$ condition was recorded to have a significant effect on thousand-grain weight for the released cultivars; the thousand-grain weight increased by $10.4 \%$ on average, while the change was not significant in the landrace (Figure 1).

Table 1. Analysis of variance results. Mean and standard error (S.E.) of phenological parameters of landrace (Gen) and released cultivars (Cul) under ambient and elevated $\mathrm{CO}_{2}$ conditions, as well as their interactions.

\begin{tabular}{|c|c|c|c|c|c|c|c|c|}
\hline Variables & Cultivar & $\mathrm{aCO}_{2}$ & $\mathrm{eCO}_{2}$ & S.E. & $\Delta \%$ & $\mathrm{CO}_{2}$ & Gen/Cul & $\mathrm{CO}_{2} \times \mathrm{Gen} / \mathrm{Cul}$ \\
\hline \multirow{2}{*}{ Plant height $(\mathrm{cm})$} & Landrace & 101.9 & 109.6 & 3.8 & 7.6 & $* * *$ & * & * \\
\hline & Released & 94.5 & 100.8 & 3.8 & 6.7 & $* * *$ & $* * *$ & ns \\
\hline \multirow[t]{2}{*}{ Vegetative biomass (g plant ${ }^{-1}$ ) } & Landrace & 35.6 & 38.3 & 2.0 & 7.6 & $* * *$ & $* * *$ & $* * *$ \\
\hline & Released & 39.4 & 43.1 & 2.0 & 9.4 & $* * *$ & $* * *$ & $* * *$ \\
\hline \multirow{2}{*}{ Stem biomass (g plant ${ }^{-1}$ ) } & Landrace & 19.3 & 21.4 & 1.4 & 10.9 & $* * *$ & $* * *$ & $* * *$ \\
\hline & Released & 21.5 & 23.7 & 1.3 & 10.2 & $* * *$ & $* * *$ & $* * *$ \\
\hline \multirow[t]{2}{*}{ Leaf biomass (g plant ${ }^{-1}$ ) } & Landrace & 11.2 & 11.4 & 0.7 & 1.8 & ns & $* * *$ & $* * *$ \\
\hline & Released & 12.6 & 13.3 & 0.7 & 5.6 & $* * *$ & $* *$ & $*$ \\
\hline \multirow[t]{2}{*}{ Ear biomass (g plant ${ }^{-1}$ ) } & Landrace & 13.2 & 16.5 & 1.8 & 25.0 & $* * *$ & $* * *$ & ns \\
\hline & Released & 11.9 & 15.6 & 1.8 & 31.1 & $* * *$ & $* *$ & ns \\
\hline \multirow{2}{*}{ Chaff (awn) biomass (g plant ${ }^{-1}$ ) } & Landrace & 5.1 & 5.5 & 1.6 & 9.0 & $* *$ & $* * *$ & $* * *$ \\
\hline & Released & 5.2 & 6.1 & 1.2 & 17.6 & $* * *$ & $* * *$ & $* * *$ \\
\hline \multirow[t]{2}{*}{ Number of ears (plant ${ }^{-1}$ ) } & Landrace & 13.8 & 15.2 & 1.8 & 10.2 & ns & $* *$ & ns \\
\hline & Released & 12.8 & 13.4 & 2.2 & 4.7 & ns & $*$ & ns \\
\hline \multirow[t]{2}{*}{ Number of grain (plant ${ }^{-1}$ ) } & Landrace & 146.0 & 193.0 & 30.9 & 32.2 & $* * *$ & $* * *$ & $* * *$ \\
\hline & Released & 134.0 & 176.0 & 34.2 & 31.3 & $* * *$ & $* * *$ & ns \\
\hline \multirow[t]{2}{*}{ Grain yield (g plant ${ }^{-1}$ ) } & Landrace & 8.1 & 10.9 & 1.7 & 34.1 & $* * *$ & $* * *$ & $* * *$ \\
\hline & Released & 6.7 & 9.42 & 1.7 & 40.6 & $* * *$ & $* * *$ & $* *$ \\
\hline \multirow{2}{*}{ Thousand-grain weight (g) } & Landrace & 54.5 & 56.2 & 3.1 & 3.1 & ns & $* * *$ & ns \\
\hline & Released & 49.2 & 54.3 & 5.6 & 10.4 & $*$ & $* *$ & ns \\
\hline \multirow{2}{*}{ Harvest index } & Landrace & 0.21 & 0.24 & 0.03 & 14.3 & $* *$ & $* * *$ & ns \\
\hline & Released & 0.16 & 0.20 & 0.03 & 23.3 & $* * *$ & $* * *$ & $* * *$ \\
\hline \multirow[t]{2}{*}{$\begin{array}{l}\text { Total water use } \\
\left(\text { WU_T, L plant }{ }^{-1}\right)\end{array}$} & Landrace & 9.2 & 9.1 & 0.1 & -1.1 & * & $* * *$ & $* * *$ \\
\hline & Released & 9.3 & 9.3 & 0.1 & 0.0 & ns & $* * *$ & $* * *$ \\
\hline \multirow{2}{*}{$\begin{array}{l}\text { Water-use efficiency of vegetative biomass } \\
\qquad\left(\text { WUE_B, } \mathrm{g} \mathrm{L}^{-1}\right)\end{array}$} & Landrace & 3.8 & 4.1 & 0.1 & 7.9 & $* * *$ & $* * *$ & $* * *$ \\
\hline & Released & 4.2 & 4.6 & 0.1 & 9.5 & $* * *$ & $* * *$ & $* * *$ \\
\hline \multirow[t]{2}{*}{ Water-use efficiency of grains (WUE_G, $\mathrm{g} \mathrm{L}^{-1}$ ) } & Landrace & 0.9 & 1.2 & 0.1 & 33.3 & $* * *$ & $* * *$ & ns \\
\hline & Released & 0.7 & 1.0 & 0.1 & 42.9 & $* * *$ & $* * *$ & ns \\
\hline
\end{tabular}

Significance level: $p<0.001\left(^{* * *}\right) ; p<0.01\left(^{* *}\right) ; p<0.05\left(^{*}\right)$; and non-significant $(\mathrm{ns})$.

In Figure 2, the correlation analysis revealed that grain yield had a positive and strong association with the number of grains $(r=0.95, p<0.001)$, ear biomass $(r=0.91$, $p<0.001)$ and harvest index $(r=0.86, p<0.001)$. In addition, the performance of the genotypes/cultivars regarding the response of grain yield under the $\mathrm{aCO}_{2}$ condition versus the $\mathrm{eCO}_{2}$ condition had a significant and positive correlation in the landrace $(r=0.64$, $p=0.01)$ and released cultivars $(r=0.93, p<0.001)$, as shown in Figure 3. Among the landrace cultivars, Lan_15 displayed the highest yield, while Lan_7 displayed the lowest yield under both the ambient and elevated $\mathrm{CO}_{2}$ conditions. Comparing the released cultivars, the highest grain yield was recorded for Rel_4, and Rel_10 had the lowest yield. Moreover, a strong and positive correlation of cultivars was recorded for grain number per plant under the $\mathrm{aCO}_{2}$ condition versus the $\mathrm{eCO}_{2}$ condition (Figure 3); however, the best genotypes under $\mathrm{aCO}_{2}$ were not always the best genotypes under $\mathrm{eCO}_{2}$ in terms of both number of grains and grain yield. 


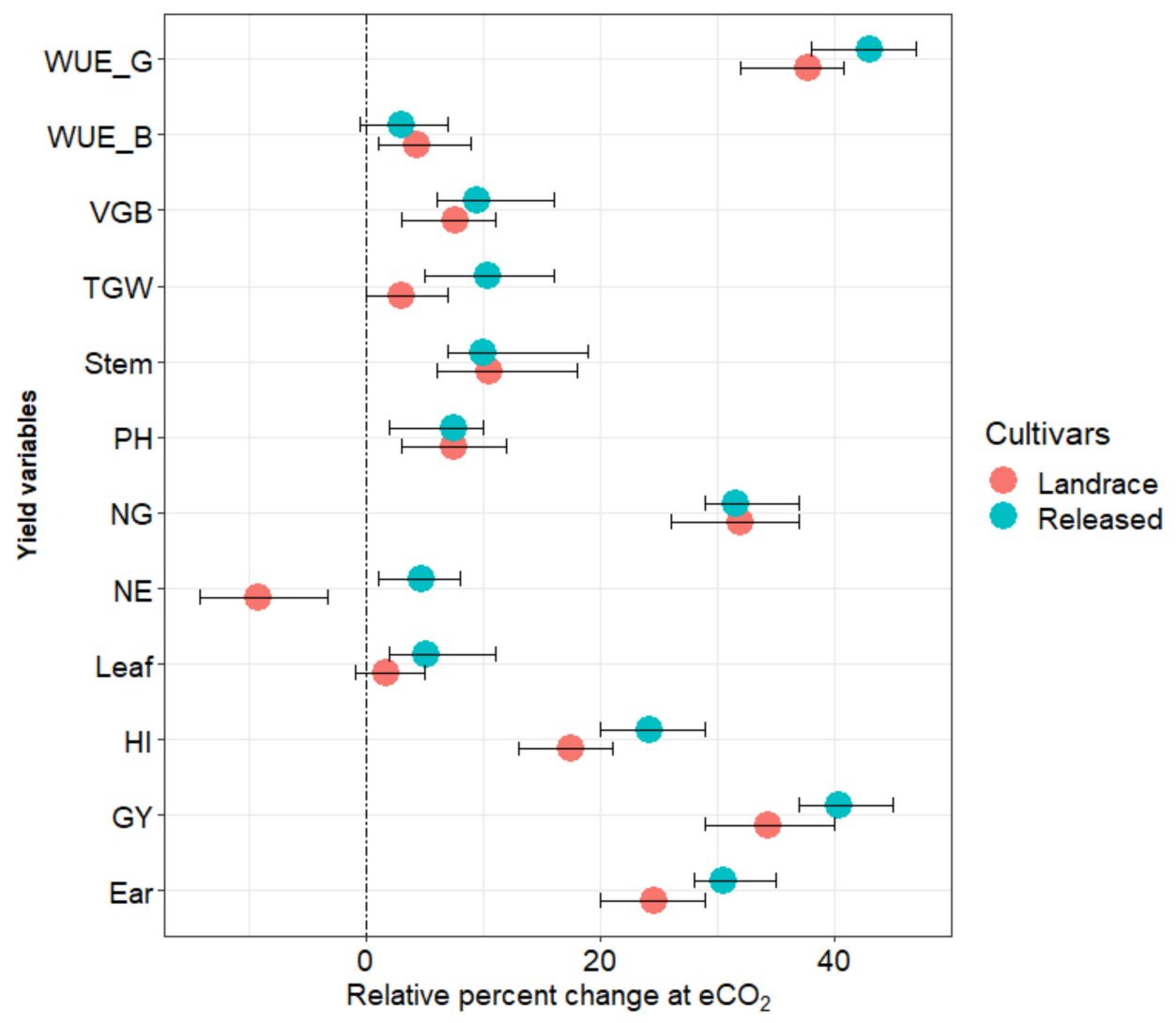

Figure 1. Relative effect of $\mathrm{eCO}_{2}$ condition on plant height, biomass fractions, yield components, and water-use efficiency of barley. Average relative changes due to $\mathrm{CO}_{2}$ enrichment against $\mathrm{aCO}_{2}$ are presented, with error bars representing their standard errors. Ear: ear biomass; GY: grain weight; HI: harvest index; Leaf: leaf biomass; NE: number of ears; NG: grain number; PH: plant height; Stem: stem biomass; TGW: thousand-grain weight; VGB: vegetative biomass; WUE_B: water-use efficiency of vegetative biomass; and WUE_G: water-use efficiency of grain.

\subsection{Water-Use Efficiency}

The variables of water-use efficiency of vegetative biomass (WUE_B) and grain (WUE_G) were significantly affected by the $\mathrm{CO}_{2}$ condition and type of cultivar $(p<0.001)$, as shown in Table 1. However, their interaction did not affect the response of total water use in both the landrace and released cultivars. In the $\mathrm{aCO}_{2}$ condition, the landrace cultivar used $9.2 \mathrm{~L}_{\text {plant }}{ }^{-1}$ of WU_T, and had $4.7 \mathrm{~g} \mathrm{~L}^{-1}$, WUE_B, and $0.9 \mathrm{~g} \mathrm{~L}^{-1}$ WUE_G (Table 1). On the other hand, the released cultivars used $9.3 \mathrm{~L}_{\text {plant }}{ }^{-1}$ of WU_T and had $4.9 \mathrm{~g} \mathrm{~L}^{-1}$ WUE_B, and $0.7 \mathrm{~g} \mathrm{~L}^{-1}$ WUE_G (Table 1). The levels of total water consumption of water by the landrace and released cultivars were not significantly different under the different $\mathrm{CO}_{2}$ levels. The effect of $\mathrm{CO}_{2}$ enrichment was higher in the response of WUE_G than WUE_B. WUE_G was increased by $33.3 \%$ in landraces and $42.9 \%$ in the released cultivars (Table 1 and Figure 1). In comparison, Lan_15 and Rel_4 showed the highest WUE_G among the landrace and released cultivars, respectively, while the lowest WUE_G was observed in Lan_6, Lan_7, and Rel_10 (Figure 4a,b). 
NG

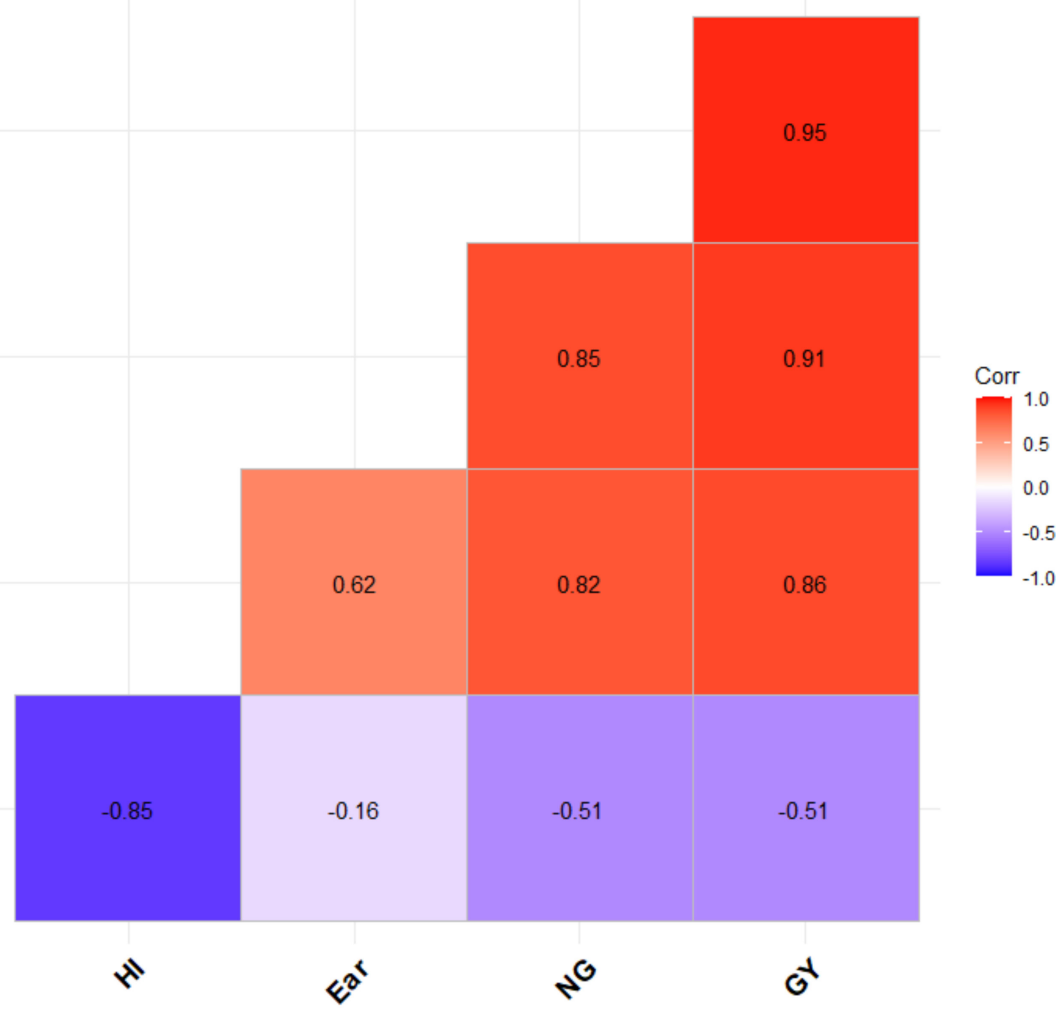

Figure 2. Correlation between grain yield, yield parameters, and water-use efficiency. VGB: vegetative biomass; Ear: ear biomass; NG: number of grains; GY: grain yield; WUE_G: water-use efficiency of grains; HI: harvest index. The value shows Pearson's correlation coefficient. The minus sign indicates a negative correlation between the variables.

a

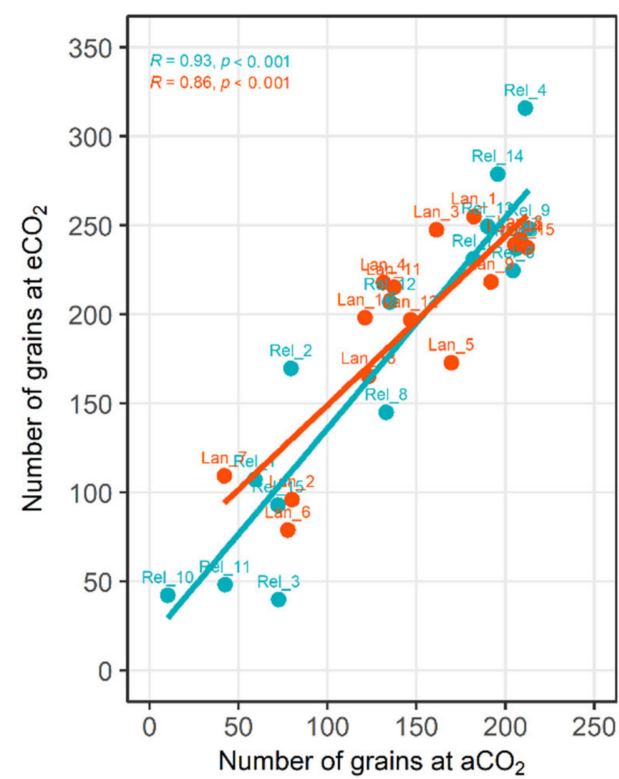

b

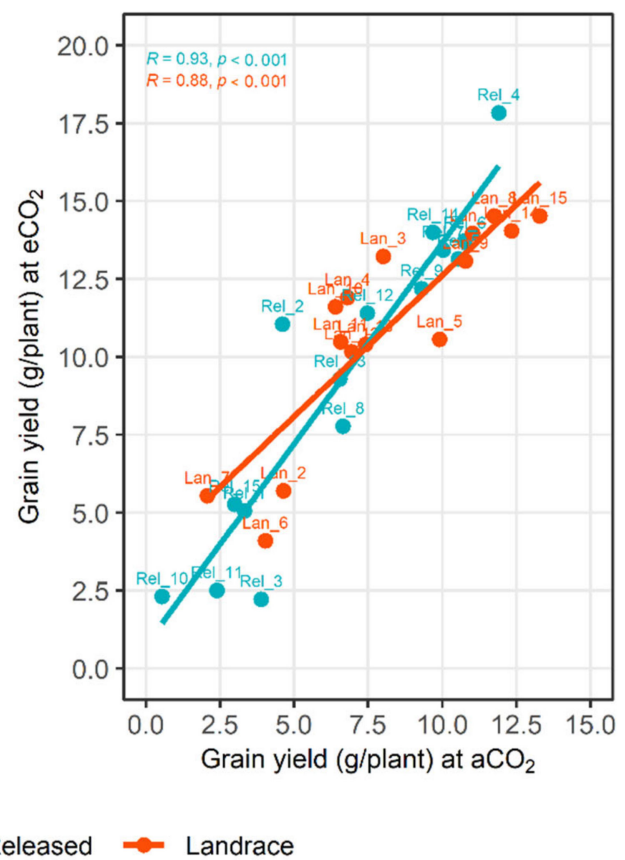

Figure 3. Mean response of landrace and released cultivars under elevated (500 ppm) $\mathrm{CO}_{2}$ plotted against mean response under ambient (400 ppm) $\mathrm{CO}_{2}$, where responses refer to (a) number of grains per plant and (b) grain yield (in grams) per plant. 


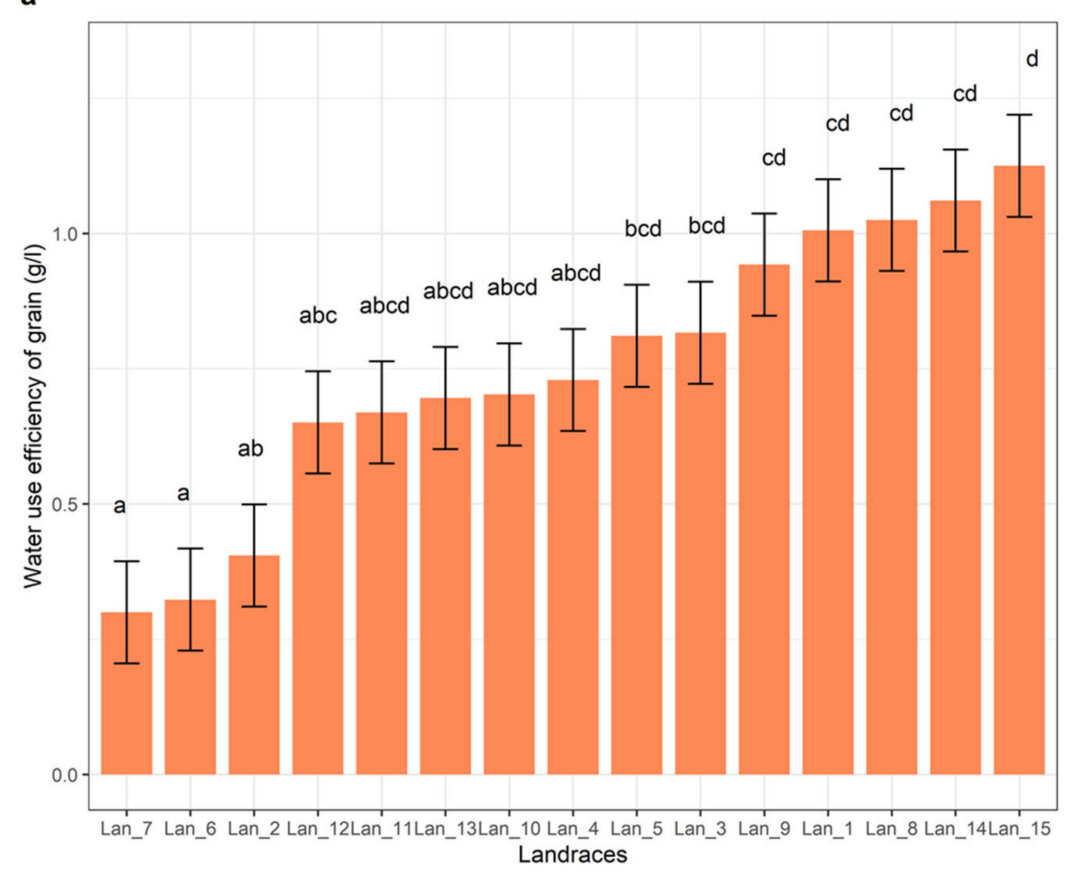

b

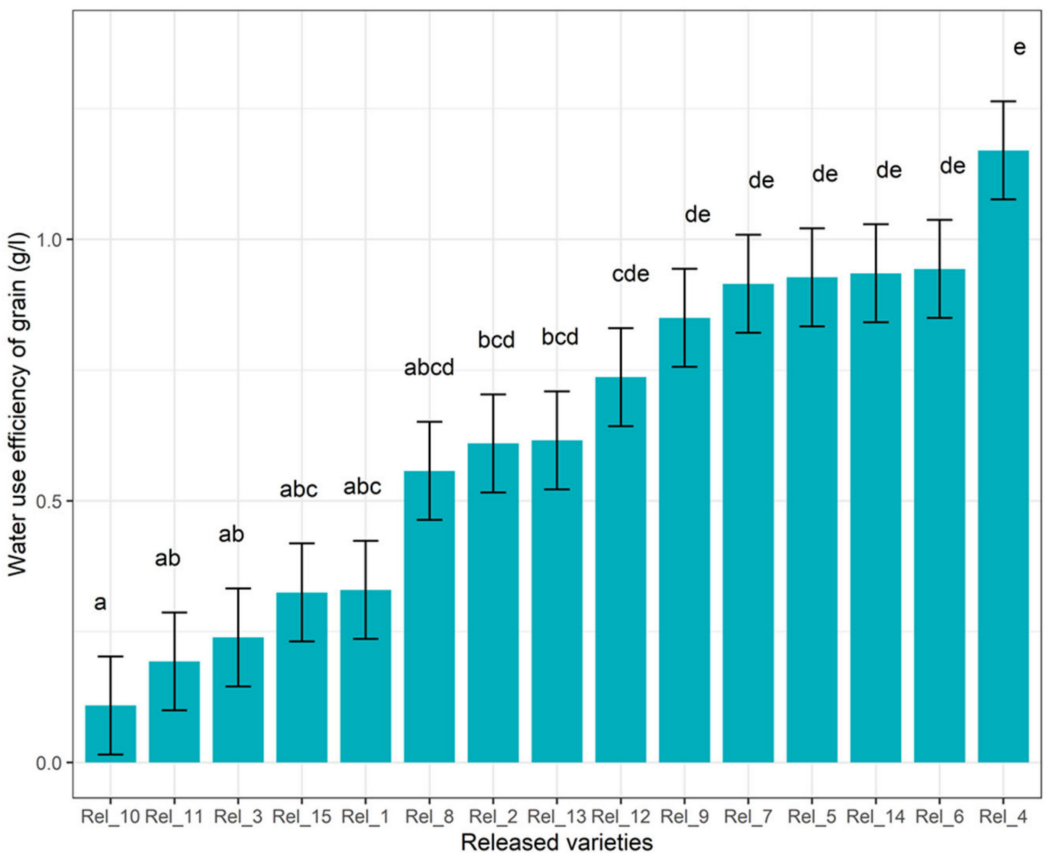

Figure 4. Mean response of landrace (a) and released cultivars (b) regarding the water-use efficiency of grains (WUE_G, $\mathrm{g} \mathrm{L}^{-1}$ ). The letters indicate the significant level between genotypes/cultivars. Mean values sharing a letter are not significantly different.

\section{Discussion}

3.1. The Overall Effect of e $\mathrm{CO}_{2}$ on Vegetative Biomass, Grain Yield, and Water-Use Efficency

Atmospheric $\mathrm{CO}_{2}$ enrichment is expected to contribute to the required increase in grain yield production in the future $[15,26,27]$. Our findings from the climate chamber experiment, where the $\mathrm{eCO}_{2}$ condition was applied as a single factor, correspond well with findings in previously published data. In the present study, on average, vegetative biomass was increased by $7.6 \%$ in landraces and $9.4 \%$ in the released cultivars, respectively. The enhancement was predominantly due to higher biomass allocation towards ear and stem biomass. The $\mathrm{eCO}_{2}$ condition was observed to have a significant effect on the response 
of leaf biomass in the released cultivars alone. In line with the present results, findings from $\mathrm{CO}_{2}$ enrichment studies regarding barley reported the significant enhancement of vegetative biomass due to higher $\mathrm{CO}_{2}$ concentrations [28-30]. A previous study [15] summarized the biomass response of the $\mathrm{C} 3$ species and reported an average enhancement of vegetative biomass by $16 \%$ under $\mathrm{eCO}_{2}$ conditions. Comparable results were also reported regarding other $\mathrm{C} 3$ crops, such as wheat [31] and rice [26].

In the present study, the released cultivars had a higher relative grain yield increase $(40.6 \%)$ under the $\mathrm{eCO}_{2}$ condition as compared to the landraces $(34.1 \%)$. This supports the hypothesis that enhanced net-photosynthesis in $\mathrm{eCO}_{2}$ conditions was unconsciously targeted through breeding. However, surprisingly, the landrace group had higher actual grain yield production levels under both the $\mathrm{aCO}_{2}$ and $\mathrm{eCO}_{2}$ conditions. In support of this finding [28], grain yield was determined via grain number per plant and ear biomass, which indicates that $\mathrm{CO}_{2}$ enrichment and the acquisition of extra carbon were carried forward to the grains rather than the biomass yield. Previous studies regarding barley $[19,20]$ and wheat $[32,33]$ reported the positive correlation of grain yield with grain number. In the current study, an average enhancement of thousand-grain weight by $10.4 \%$ due to $\mathrm{eCO}_{2}$ conditions was recorded in the released cultivars, whereas the response was not significantly affected in the landraces. In line with our findings, a study regarding wheat reported an enhancement of thousand-grain weight by 3.8-7.0\% [34]; on the other hand, a non-significant effect of $\mathrm{eCO}_{2}$ conditions on the thousand-grain weight of barley and wheat was reported in other studies [20,35]. The effects of $\mathrm{eCO}_{2}$ conditions on the harvest index have been reviewed in rice, wheat, and soybean, with contradictory results. In the present study, the harvest index was increased by 23.3 and $14.3 \%$ in the released and landrace cultivars, respectively, under the $\mathrm{eCO}_{2}$ condition. Similarly, in [27], a significant increase in the harvest index was also displayed in rice under $\mathrm{eCO}_{2}$ conditions, which was contrary to a decrease in harvest indexes related to soybean and wheat $[26,36]$. The actual grain yield of landrace observed in the present study was higher compared to that of the released cultivars; however, the positive effect of $\mathrm{eCO}_{2}$ was greater in the released cultivars. Accordingly, the relative percentage change of the harvest index was observed to be higher for the released cultivars compared to the landraces. Our finding supports the effort of breeding to reduce the percentage of vegetative biomass to increase the harvest index of crops, which is in line with the findings of [17].

As $\mathrm{CO}_{2}$ levels rise above the current ambient level, photosynthesis is commonly enhanced and transpiration is frequently reduced, resulting in greater water efficiency and increased plant growth and productivity [37]. In the present study, a significant improvement regarding WUE_G was displayed. Average enhancements in the values of WUE_G by 33.3 and $42.9 \%$ were observed in the landrace and released cultivars, respectively, under the $\mathrm{eCO}_{2}$ condition. In agreement with these findings, previous studies reported that $\mathrm{eCO}_{2}$ conditions had a significant effect on the WUE_G and WUE_B values of barley and other crops. For instance, a study regarding two barley cultivars reported a significant enhancement of water-use efficiency of vegetative biomass and grain under well-watered conditions [17]. Furthermore, increases in WUE values by $20 \%$ under well-watered and by $42 \%$ under drought conditions, due to the presence of $\mathrm{eCO}_{2}$, were reported [29]. Regarding wheat, the authors of $[38,39]$ reported a significant enhancement of WUE_B and WUE_G values due to high $\mathrm{eCO}_{2}$ conditions. On the other hand, the author of [40] revealed a clear reduction in the water consumption of barley under $\mathrm{eCO}_{2}$ conditions. The current study, as well as several previous studies, revealed that $\mathrm{eCO}_{2}$ conditions cause increases in water-use efficiency values by increasing growth and yield more so than by increasing water consumption. This would be beneficial for use in future food production, especially in water-limited areas.

\subsection{Cultivar Specific Responses to e $\mathrm{CO}_{2}$ on Barley Production}

In this study, a wide range of intraspecific variation was observed in the responses of the measured yield parameters to the $\mathrm{eCO}_{2}$ condition, from negative to large increments. 
The response of grain yield to the $\mathrm{eCO}_{2}$ condition ranged from $-25 \%$ (Lan_14) to $+122.3 \%$ (Lan_15) in the landraces, while the released cultivars showed a $42 \%$ reduction in grain yield (Rel_3) to an increment of $140.2 \%$ (Rel_10) under the $\mathrm{eCO}_{2}$ condition. High grain yield and stability were found among landraces and the released cultivars. The landraces originated and were grown in different altitudes, indicating that suitable resources for climate resilience are available from different areas. The highest yielding landraces were Lan_15, Lan_8, Lan_1, Lan_9, and Lan_6 under both the $\mathrm{aCO}_{2}$ and $\mathrm{eCO}_{2}$ conditions. The highest yielding landraces were grown in various parts of Ethiopia between 1642 and 3570 m.a.s.l, indicating the diversity and potential of choosing cultivars for future climate conditions. On the other hand, the highest yielding released cultivars were Rel_4, Rel_5, Rel_6, Rel_7, and Rel_10, which were characterized by early maturation, high yields, and resistance to lodging and leaf diseases (Pyrenophora teres and Rhynchosporium secalis). As shown in our findings, $\mathrm{CO}_{2}$ enrichment studies regarding different barley cultivars reported a significant variation among cultivars in the response of grain yield and its parameters $[20,21,41]$. The greater enhancement of ear biomass per plant and improvement regarding WUE_G values significantly contributed to the observed grain yield gain in the highest yielding cultivars. In line with these findings, several studies have reported that barley yield responses to $\mathrm{CO}_{2}$ conditions are mostly cultivar dependent $[19,23,42]$. Studies involving other $\mathrm{C} 3$ crops have also reported significant differences between cultivars tested in future climate change scenarios. Variations in the responses to $\mathrm{eCO}_{2}$ conditions in rice cultivars, for example, have been recorded, ranging from a $31 \%$ yield reduction to a $41 \%$ yield gain $[24,43]$. Similarly, significant variation in yield response under $\mathrm{eCO}_{2}$ conditions, ranging from 20 to $80 \%$, was observed in soybean cultivars [44]. Further variations in yield response were observed in other studies, with yield gains of between 31 and $41 \%$ being found [24,43]. As has been seen in previous studies, in the present study, negative growth effects of $\mathrm{eCO}_{2}$ were observed regarding vegetative biomass and grain yield. The negative yield responses may partly be associated with alterations in the shoot: root carbon allocation between the cultivars examined. Previous studies reported positive root growth effects in barley via $\mathrm{eCO}_{2}$ conditions [45,46]. Cultivars with negative vegetative biomass accumulation under $\mathrm{eCO}_{2}$ were allotted newly assimilated carbon, but this would preferentially take place below the ground level for the enhanced development of their root systems at the expense of the vegetative biomass [21]. A review of different experiments conducted under $\mathrm{eCO}_{2}$ conditions listed $13 \mathrm{C} 3$-plant species that exhibited reductions in vegetative biomass by up to $42 \%$ [47]. A set of more than 100 spring barley cultivars grown under $\mathrm{eCO}_{2}$ conditions yielded negative responses comparable to the current findings [48]. In general, studies on $\mathrm{C} 3$ crops indicate that intraspecific yield variations under $\mathrm{eCO}_{2}$ conditions are primarily related to changes in carbon allocation within cultivars, rather than physiological traits related to carbon assimilation $[45,46]$. The current study, as well as other similar studies, have found a wide range of $\mathrm{eCO}_{2}$ responsiveness in some of the world's most important food crops, implying that selecting for $\mathrm{eCO}_{2}$ responsiveness may ensure long-term productivity under $\mathrm{eCO}_{2}$ conditions $[18,26,49,50]$. The Lan_15, Lan_8, Lan_1, Lan_9, and Lan_6 variants among the landraces and the Rel_4, Rel_5, Rel_6, Rel_7, and Rel_10 variants among the released cultivars are the top five highest-yielding variants due to improved grain number values under the $\mathrm{eCO}_{2}$ condition. They represent important genetic resources for use in future barley breeding programs. Despite the overall positive correlation of genotypes/cultivars, the best genotypes under $\mathrm{aCO}_{2}$ might not always be the best genotypes under $\mathrm{eCO}_{2}$; thus, direct selection under $\mathrm{eCO}_{2}$ is needed to identify the best varieties for future climates.

\section{Materials and Methods}

\subsection{Genetic Material and $\mathrm{CO}_{2}$ Enrichment}

Thirty Ethiopian barley cultivars consisting of 15 landraces and 15 released cultivars were obtained from Holetta Agricultural Research Centre (HARC) in Ethiopia. The landraces represent dominant barley landraces that are cultivated in different parts of 
Ethiopia. The released cultivars were chosen based on their diversity regarding adaptation and genetic background. They were released from 1975, are grown in different parts of the country, and differ in their traits such as grain yield (Figure A1, Tables 2 and A1). The cultivars were cultivated in six identical climate chambers (Vötsch BioLine, Balingen, Germany) in which the climatic variables could be controlled. To mimic a realistic seasonal climate within the climate chambers, the daily temperature and relative humidity mean of Holeta from the period 2008-2018, and which are registered at World Weather Online (https: / / www.worldweatheronline.com, accessed on 12 January 2019), was used. In total, 27 weekly climate profiles were derived from these 10-year time series, representing the main growing season in Ethiopia. The day length $(12 \mathrm{~h})$ and the daily temperatures (daily mean of the coldest week: $8{ }^{\circ} \mathrm{C}$; daily mean of the warmest week: $25^{\circ} \mathrm{C}$ ) were adapted. The $\mathrm{CO}_{2}$ concentration within the chambers did not follow any time course but was set to constant values of $400 \mathrm{ppm}$ in three chambers (ambient concentration, $\mathrm{aCO}_{2}$ ) and $550 \mathrm{ppm}$ in another three chambers (elevated concentration, $\mathrm{eCO}_{2}$ ).

\subsection{Plant Cultivation and Measurement of Plant-Related Parameters}

The polyvinyl chloride pots used in the experiment were $40 \mathrm{~cm}$ in height and $10.3 \mathrm{~cm}$ in diameter, with a total volume of $3.33 \mathrm{~L}$ and a surface area of $83.33 \mathrm{~cm}^{2}$. These pots were filled with $3.3 \mathrm{~kg}$ of sand and standard soil (Fruhstorfer Erde LD80, Hawita GmbH, Vechta, Germany) with a 2:1 ratio. The standard soil, LD80, comprised $50 \%$ peat, $35 \%$ volcanic clay, and $15 \%$ bark humus, and it was enriched with slow-releasing fertilizers. The $\mathrm{pH}$ $\left(\mathrm{CaCl}_{2}\right)$ of the medium was 5.9 , the organic matter content was $35 \%$ (loss-on-ignition), and the salt content was $1 \mathrm{~g} \mathrm{~L}^{-1} \mathrm{KCl}$. The nutrient availability of the LD80 standard medium was $\left(\mathrm{mg} \mathrm{L}^{-1}\right) 150 \mathrm{~N}, 150 \mathrm{P}_{2} \mathrm{O}_{5}$, and $250 \mathrm{~K}_{2} \mathrm{O}$. Per cultivar, five seeds were grown and thinned at the seedling stage in two experimental plants per pot. Once a week, pots and $\mathrm{CO}_{2}$ treatments were rotated between chambers to avoid any potential chamber effects. Plants were watered with $500 \mathrm{~mL}$ at the beginning of the experiment and were regularly watered throughout with an adequate amount to avoid drought. Pots were weighed once a week and adjusted to a weight of $5 \mathrm{~kg}$ to monitor differences in the water consumption of plants from different $\mathrm{CO}_{2}$ treatments over time. The total water consumption ranged between 8.6 and $9.7 \mathrm{~L}$ in landraces and between 8.7 and $9.8 \mathrm{~L}$ in released cultivars. The values of total water use (WU_T, Equation (1)), water-use efficiency of vegetative biomass (WUE_B, Equation (2)), and water-use efficiency of grain yield (WUE_G, Equation (3)) were calculated.

When the plants reached full maturity, plant height and total pot weight were measured before harvesting. Afterward, plants were harvested and separated into the vegetative biomass fractions (leaves, stems, and reproductive organs/ears). The single plant fractions were oven-dried at $30^{\circ} \mathrm{C}$ (reproductive organs/ears) and $60^{\circ} \mathrm{C}$ (stems and leaves) until they reached a constant weight before their dry weight was determined. The share to which single plant fractions contributed to total plant biomass was calculated and given as leaf, stem, and ear dry matter weight per plant. Grains were removed from the ears by manual threshing to determine the total grain yield, thousand-grain weight, and grain number, as well as the harvest index per plant.

$$
\begin{aligned}
W U_{T} & =\frac{\text { Total water applied }(L)}{\text { Plant }} \\
W U E_{B} & =\frac{\text { Biomass yield }(g)}{\text { Total water applied }(L)} \\
W U E_{G} & =\frac{\text { Grain yield }(g)}{\text { Total water applied }(L)}
\end{aligned}
$$




\subsection{Statistical Analyses}

The experiment was conducted using a randomized split-plot design with three replicates per $\mathrm{CO}_{2}$ treatment level; the $\mathrm{CO}_{2}$ treatment level was used as the main plot factor. The two levels of $\mathrm{CO}_{2}$ were randomly assigned to a climate chamber, and cultivars were randomly placed in a climate chamber. Once a week, pots and $\mathrm{CO}_{2}$ treatments were rotated between chambers to avoid any potential chamber effects. Following the experimental design, a two-way analysis of variance (ANOVA) was applied to test the significance of the main effects of genotype/cultivar and $\mathrm{CO}_{2}$ treatments, as well as their interactions regarding both the landrace and released cultivars. In addition, the main effects of altitude and its interaction with $\mathrm{CO}_{2}$ levels were analyzed regarding the landrace. Means were separated using Tukey HSD post hoc tests. Pearson's correlation coefficients were calculated to compare response variables and the performance of cultivars under the $\mathrm{aCO}_{2}$ condition versus the $\mathrm{eCO}_{2}$ condition. All the analyses were performed using the $\mathrm{R}$ programming language, version 4.0.1 [51].

\section{Conclusions}

Elevated $\mathrm{CO}_{2}$ is beneficial to barley growth, yield, and water-use efficiency. The present study evaluated thirty Ethiopian barley cultivars and showed that $\mathrm{eCO}_{2}$ levels provoke a significant enhancement of vegetative biomass and grain yield values. In comparison, grain yield was much more responsive to the $\mathrm{eCO}_{2}$ condition than vegetative biomass, mainly due to a significant enhancement of the ear biomass value, grain number, and harvest index. The water-use efficiency of vegetative biomass and the water-use efficiency of grain was enhanced in future climate condition. The grain yield gain was positively associated with the high grain number and water-use efficiency of grain per plant. On average, the released cultivars benefited more from $\mathrm{CO}_{2}$ fertilization than the landraces. However, a wide range of intraspecific variation was observed within the responses of biomass and grain yield parameters across both the landrace and released cultivars. For instance, the cultivars Lan_15 and Rel_ 4 were the highest yielding variants among the landrace and released cultivars, respectively, under the current and future $\mathrm{CO}_{2}$ levels and represent important genetic resources for use in the future barley breeding in Ethiopia. The investigation of the interaction between cultivar types and the environment could help to better understand the thresholds for cultivars' performance under climate change conditions. Grain yield production under future climate conditions could benefit from the identification of cultivars with higher grain numbers and more efficient water use in grain. However, food security involves more than just production. Further attention is required regarding the investigation of the nutritional quality of barley cultivars under $\mathrm{eCO}_{2}$ conditions. Moreover, the growth and stress tolerance values of Ethiopian barley cultivars in response to the interactive effects of $\mathrm{eCO}_{2}$ conditions, warming, and drought should be examined in order to achieve better exploitation of germplasm resources under changing climatic conditions.

Author Contributions: M.W.G. conceived and designed the study; data collection was carried out by M.W.G.; M.W.G. and W.A.M. participated in the analysis of the data; M.W.G. wrote the paper, with substantial input from B.I.G.H. and W.A.M. All authors have read and agreed to the published version of the manuscript.

Funding: This publication is an output of a Ph.D. scholarship from the University of Hohenheim in the framework of the project "German-Ethiopian SDG Graduate School: Climate Change Effects on Food Security (CLIFOOD)" between the University of Hohenheim (Germany) and the Hawassa University (Ethiopia), supported by the DAAD with funds from the Federal Ministry for Economic Cooperation and Development (BMZ). Funding grant number 57316245.

Institutional Review Board Statement: Not applicable.

Informed Consent Statement: Not applicable. 
Data Availability Statement: The data presented in this study are available upon request from the corresponding author.

Acknowledgments: The authors are grateful to Petra Högy, Gina Gensheimer, Annette Falter, and Jürgen Franzaring for their help during the climate chamber experiment. Additionally, special thanks go to the team members and coordinators of the CLIFOOD project. We would also like to acknowledge the support received through the DFG grant PI 377/24-1. Furthermore, we are grateful to Berhane Lakew and Holeta Agricultural Research Center for providing us with barley cultivars.

Conflicts of Interest: The authors declare no conflict of interest.

\section{Appendix A}

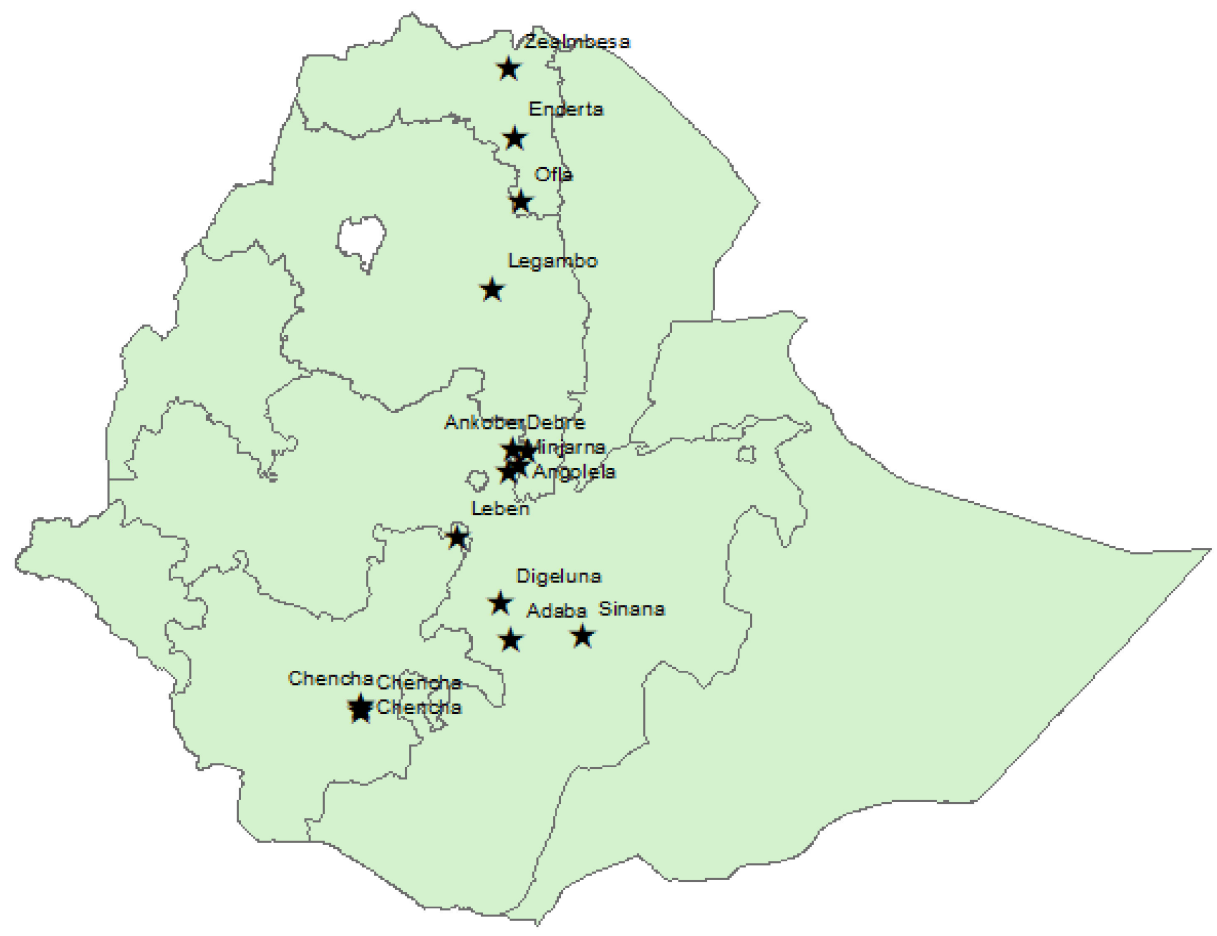

Figure A1. Map of origin of Ethiopian landrace cultivar collection.

Table A1. List of Ethiopian landrace cultivars and the origin of the collection.

\begin{tabular}{cccccccc}
\hline Code & Cultivars & Region & Zone & Woreda & Latitude & Longitude & Altitude \\
\hline Lan_1 & 215217-A & Amara & Debub & Legambo & $11-39-00-\mathrm{N}$ & $39-00-00-\mathrm{E}$ & 3570 \\
Lan_2 & 18330-A & Amara & Semen & Angolela & $09-18-00-\mathrm{N}$ & $39-32-25-\mathrm{E}$ & 3325 \\
Lan_3 & $219578-\mathrm{A}$ & Amara & Semen & Debre & $09-37-00-\mathrm{N}$ & $39-25-00-\mathrm{E}$ & 2690 \\
Lan_4 & 243410 & Amara & Semen & Ankober & $09-36-00-\mathrm{N}$ & $39-44-00-\mathrm{E}$ & 2350 \\
Lan_5 & 237021 & Amara & Semen & Minjarna & $09-10-20-\mathrm{N}$ & $39-20-00-\mathrm{E}$ & 1750 \\
Lan_6 & $208816-\mathrm{A}$ & Oromiya & Bale & Adaba & $07-00-20-\mathrm{N}$ & $39-23-30-\mathrm{E}$ & 3500 \\
Lan_7 & 237015 & Oromiya & Arssi & Digeluna & $07-45-00-\mathrm{N}$ & $39-11-00-\mathrm{E}$ & 2600 \\
Lan_8 & $64233-\mathrm{C}$ & Oromiya & Bale & Sinana & $07-04-00-\mathrm{N}$ & $40-14-00-\mathrm{E}$ & 2460 \\
Lan_9 & 18327 & Oromiya & Semen & Leben & $08-28-00-\mathrm{N}$ & $38-56-59-\mathrm{E}$ & 1642 \\
Lan_10 & 216997 & SNNP & Semen & Chencha & $06-17-00-\mathrm{N}$ & $37-35-00-\mathrm{E}$ & 3030 \\
Lan_11 & 208845 & SNNP & Semen & Chencha & $06-15-00-\mathrm{N}$ & $37-35-00-\mathrm{E}$ & 2850 \\
Lan_12 & 234307 & Tigray & Misrak Awi & Zealmbesa & $14-16-00-\mathrm{N}$ & $39-21-00-\mathrm{E}$ & 3100 \\
Lan_13 & 234293 & Tigray & Debub Awi & Ofla & $12-48-00-\mathrm{N}$ & $39-35-00-\mathrm{E}$ & 2410 \\
Lan_14 & 237339 & Tigray & Debub Awi & Enderta & $13-30-00-\mathrm{N}$ & $39-28-00-\mathrm{E}$ & 2240 \\
Lan_15 & 221325 & SNNP & Semen & Chencha & $06-09-00-\mathrm{N}$ & $37-36-00-\mathrm{E}$ & 2150 \\
\hline
\end{tabular}


Table 2. List of Ethiopian released cultivars and their desired trait.

\begin{tabular}{|c|c|c|c|c|}
\hline Code & Cultivars & Genetic Background/Pedigree & Year of Released & $\begin{array}{c}\text { Desirable Traits of the Cultivars } \\
\text { Other than Yield }\end{array}$ \\
\hline Rel_1 & Gobe & $\begin{array}{l}\text { IICARDA } \\
\text { germplasm-CBSS96Moo487T-D-1M-1Y-2M-oY }\end{array}$ & 2012 & \\
\hline Rel_2 & Cross $41 / 98$ & (50-16/3316-03)//(HB42/Alexis) & 2012 & High yielding, late maturing \\
\hline Rel_3 & EH 1493 & White Sasa/Comp29//White Sasa/EH538/F2-12B-2 & 2012 & High yielding, late maturing \\
\hline Rel_4 & EH1847 & EH1847/F4.2P.5.2 (Beka/IBON64/91) & 2011 & \\
\hline Rel_5 & Bekji-1 & EH 1293/F2-18B-11-1-14-18 & 2010 & \\
\hline Rel_6 & HB-1307 & EH-1700/F7. B1.63.70 & 2006 & $\begin{array}{l}\text { High yield, lodging resistant, } \\
\text { resistant to leaf diseases } \\
\text { (Pyrenophora teres and } \\
\text { Rhynchosporium secalis), good } \\
\text { biomass yield, and white seeded }\end{array}$ \\
\hline Rel_7 & Misccal-21 & $\begin{array}{c}\text { Azafran = Shyri } / / \text { Gloria } / \text { Copal } / 3 / \text { Shyri } / \text { Grit; } \\
\text { CMB87.643-2A }\end{array}$ & 2006 & $\begin{array}{l}\text { High yield with good malting } \\
\text { quality; resistance to lodging with } \\
\text { multiple disease resistance }\end{array}$ \\
\hline Rel_8 & Meserach & Pure line selection- Kulumsa1/88 & 1998 & $\begin{array}{c}\text { Early maturing and tolerant to major } \\
\text { leaf diseases (Pyrenophora teres and } \\
\text { Rhynchosporium secalis) }\end{array}$ \\
\hline Rel_9 & HB-42 & EIAR cross-IAR-H-81/comp29//comp14-20/coast & 1984 & $\begin{array}{c}\text { Resistant to scalding } \\
\text { (Rhynchosporium secalis) and good } \\
\text { biomass yield }\end{array}$ \\
\hline Rel_10 & $\mathrm{IAR} / \mathrm{H} / 485$ & Pure line selection from local landrace in Arsi & 1975 & \\
\hline Rel_11 & Ardu 12-60B & Pure line selection from local landrace in Arsi & 1986 & \\
\hline Rel_12 & Balemi & Dominant farmers varieties in West shoa & 1970 & $\begin{array}{l}\text { Tolerant to low soil fertility and } \\
\text { drought, good flour quality }\end{array}$ \\
\hline Rel_13 & HB-1964 & RECLA78//SHYRI/GRIT/3/ATAH92/GOB & 2016 & \\
\hline Rel_14 & HB-1965 & Awra gebs X IBON64/91 & 2017 & \\
\hline Rel_15 & HB-1966 & CARDO/CHEVRON-BAR CBSS 96 WM 00019s & 2017 & \\
\hline
\end{tabular}

\section{References}

1. Prosekov, A.Y.; Ivanova, S.A. Food security: The challenge of the present. Geoforum 2018, 91, 73-77. [CrossRef]

2. Newton, A.; Johnson, S.; Gregory, P. Implications of climate change for diseases, crop yields and food security. Euphytica 2011, 179, 3-18. [CrossRef]

3. Food and Agriculture Organization of the United Nations. FAOSTAT Database. Available online: http://www.fao.org/faostat/ en/\#data/QC (accessed on 19 August 2019).

4. Bekele, B.; Alemayehu, F.; Lakew, B. Food Barley in Ethiopia. In Food Barley: Importance, Uses, and Local Knowledge; Grando, S., Macpherson, H.G., Eds.; ICARDA: Aleppo, Syria, 2005; pp. 53-82.

5. Lakew, B.; Semeane, Y.; Alemayehu, F.; Gebre, H.; Grando, S.; Van Leur, J.A.G.; Ceccarelli, S. Exploiting the diversity of barley landraces in Ethiopia. Genet. Resour. Crop Evol. 1997, 44, 109-116. [CrossRef]

6. Asfaw, Z. The Barleys of Ethiopia. In Genes in the Field: On-farm Conservation of Crop Diversity; Stephen, B.B., Ed.; Lewis Publishers: Boca Raton, FL, USA, 2000; ISBN 1-55250-327-5.

7. Bonman, J.; Bockelman, H.; Jackso, L.; Steffenson, B. Disease and insect resistance in cultivated barley accessions from the USDA national small grains collection. Crop Sci. 2005, 45, 1271-1280. [CrossRef]

8. Mekonnon, B.; Lakew, B.; Dessalegn, T. Genotypic Diversity and Interrelationship of Characters in Ethiopian Food Barley (Hordeum vulgare L.) Landraces. Int. J. Plant Breed. Genet. 2014, 8, 164-180. [CrossRef]

9. Shewayrga, H.; Sopade, P. Ethnobotany, diverse food uses, claimed health benefits and implications on conservation of barley landraces in North-Eastern Ethiopia Highlands. J. Ethnobiol. Ethnomedicine 2011, 7, 19-34. [CrossRef] [PubMed]

10. Wosene, G.A.; Berhane, L.; Bettina, I.G.H.; Karl, J.S. Ethiopian barley landraces show higher yield stability and comparable yield to improved varieties in multi-environment field trials. J. Plant Breed. Crop Sci. 2015, 7, 275-291. [CrossRef]

11. Intergovernmental Panel on Climate Change. Mitigation of Climate Change; Intergovernmental Panel on Climate Change: Geneva, Switzerland, 2014.

12. Meehl, G.A.; Stocker, T.F.; Collins, W.D.; Friedlingstein, P.; Gaye, A.T.; Gregory, J.M.; Zhao, Z.C. Global Climate Projections: The Physical Science Basis. Contribution of Working Group I to the Fourth Assessment Report of the Intergovernmental Panel on Climate Change. Clim. Chang. 2007, 2007, 1-10.

13. Cure, J.D.; Acock, B.; Ford, M.A.; Thorne, G.N.; Fuel, L.; Lichtenthaler, H.K.; Seneweera, S. Effect of increased atmospheric carbon dioxide concentration on plant communities. Ann. Bot. 1998, 31, 416-489.

14. Kimball, B.A.; Kobayashi, K.; Bindi, M. Responses of agricultural crops to free-air $\mathrm{CO}_{2}$ enrichment. Adv. Agron. 2014, 77, 293-368. 
15. Long, S.P.; Ainsworth, E.A.; Leakey, A.D.B.; Nösbsrger, J.; Ort, D.R. Food for thought: Lower-than-expected crop yield stimulation with rising $\mathrm{CO}_{2}$ concentrations. Science 2006, 312, 1918-1921. [CrossRef] [PubMed]

16. Aspinwall, M.J.; Loik, M.E.; de Dios, V.R.; Tjoelker, M.G.; Payton, P.R.; Tissue, D.T. Utilizing intraspecific variation in phenotypic plasticity to bolster agricultural and forest productivity under climate change. Plant Cell Environ. 2015, 38, 1752-1764. [CrossRef] [PubMed]

17. Schmid, I.; Franzaring, J.; Müller, M.; Brohon, N.; Calvo, O.C.; Högy, P.; Fangmeier, A. Effects of $\mathrm{CO}_{2}$ Enrichment and Drought on Photosynthesis, Growth, and Yield of an Old and a Modern Barley Cultivar. J. Agron. Crop Sci. 2016, 202, 81-95. [CrossRef]

18. Ziska, L.H.; Bunce, J.A.; Shimono, H.; Gealy, D.R.; Baker, J.T.; Newton, P.C.D.; Reynolds, M.P.; Jagadish, K.S.V.; Zhu, C.; Howden, M.; et al. Security, and climate change: On the potential to adapt global crop production by active selection to rising atmospheric carbon dioxide. Proc. R. Soc. B Biol. Sci. 2012, 279, 4097-4105. [CrossRef] [PubMed]

19. Alemayehu, F.R.; Frenck, G.; van der Linden, L.; Mikkelsen, T.N.; Jørgensen, R.B. Can barley (Hordeum vulgare L. s.l.) adapt to fast climate changes? A controlled selection experiment. Genet. Resour. Crop Evol. 2014, 61, 151-161. [CrossRef]

20. Clausen, S.K.; Frenck, G.; Linden, L.G.; Mikkelsen, T.N.; Lunde, C.; Jørgensen, R.B. Effects of Single and Multifactor Treatments with Elevated Temperature, $\mathrm{CO}_{2}$ and Ozone on Oilseed Rape and Barley. J. Agron. Crop Sci. 2011, 197, 442-453. [CrossRef]

21. Mitterbauer, E.; Enders, M.; Bender, J.; Erbs, M.; Habekuß, A.; Kilian, B.; Weigel, H.J. Growth response of 98 barley (Hordeum vulgare L.) cultivars to elevated $\mathrm{CO}_{2}$ and identification of related quantitative trait loci using genome-wide association studies. Plant Breed. 2017, 136, 483-497. [CrossRef]

22. Manderscheid, R.; Weigel, H.J. Photosynthetic and growth responses of old and modern spring wheat cultivars to atmospheric $\mathrm{CO}_{2}$ enrichment. Agric. Ecosyst. Environ. 1997, 64, 65-73. [CrossRef]

23. Ziska, L.H.; Morris, C.F.; Goins, E.W. Quantitative and qualitative evaluation of selected wheat varieties released since 1903 to increasing atmospheric carbon dioxide: Can yield sensitivity to carbon dioxide be a factor in wheat performance? Glob. Chang. Biol. 2004, 10, 1810-1819. [CrossRef]

24. Shimono, H.; Okada, M.; Yamakawa, Y.; Nakamura, H.; Kobayashi, K.; Hasegawa, T. Genotypic variation in rice yield enhancement by elevated $\mathrm{CO}_{2}$ relates to growth before heading, and not to maturity group. J. Exp. Bot. 2009, 60, 523-532. [CrossRef] [PubMed]

25. Bourgault, M.; Dreccer, M.F.; James, A.T.; Chapman, S.C. Genotypic variability in the response to elevated $\mathrm{CO}_{2}$ of wheat lines differing in adaptive traits. Funct. Plant Biol. 2013, 40, 172-184. [CrossRef] [PubMed]

26. Ainsworth, E.A. Rice production in a changing climate: A meta-analysis of responses to elevated carbon dioxide and elevated ozone concentration. Glob. Chang. Biol. 2008, 14, 1642-1650. [CrossRef]

27. Korres, N.E.; Norsworthy, J.; Tehranchian, P.; Gitsopoulos, T.K.; Loka, D.A.; Oosterhuis, D.M.; Gealy, D.R.; Moss, S.R.; Burgos, N.R.; Miller, M.R.; et al. Cultivars to face climate change effects on crops and weeds: A review. Agron. Sustain. Dev. 2016, 36, 12. [CrossRef]

28. Fangmeier, A.; Chrost, B.; Högy, P.; Krupinska, $\mathrm{K} \mathrm{CO}_{2}$ enrichment enhances flag leaf senescence in barley due to greater grain nitrogen sink capacity. Environ. Exp. Bot. 2000, 44, 151-164. [CrossRef]

29. Manderscheid, R.; Weigel, H.J. Drought stress effects on wheat are mitigated by atmospheric $\mathrm{CO}_{2}$ enrichment. Agron. Sustain. Dev. 2007, 27, 79-87. [CrossRef]

30. Johannessen, M.M.; Mikkelsen, T.N.; Nersting, L.G.; Gullord, M.; Von Bothmer, R.; Jørgensen, R.B. Effects of increased atmospheric $\mathrm{CO}_{2}$ on varieties of oat. Plant Breed. 2005, 124, 253-256. [CrossRef]

31. Weigel, H.J.; Manderscheid, R. Crop growth responses to free-air $\mathrm{CO}_{2}$ enrichment and nitrogen fertilization: Rotating barley, ryegrass, sugar beet, and wheat. Eur. J. Agron. 2012, 43, 97-107. [CrossRef]

32. Högy, P.; Franzaring, J.; Schwadorf, K.; Breuer, J.; Schütze, W.; Fangmeier, A. Effects of free-air $\mathrm{CO}_{2}$ enrichment on energy traits and seed quality of oilseed rape. Agric. Ecosyst. Environ. 2010, 139, 239-244. [CrossRef]

33. Wu, D.; Wang, X.G.X.; Bai, Y.F.; Liao, J.X. Effects of elevated $\mathrm{CO}_{2}$ concentration on growth, water use, yield and grain quality of wheat under two soil water levels. Agric. Ecosyst. Environ. 2004, 104, 493-507. [CrossRef]

34. Högy, P.; Keck, M.; Niehaus, K.; Franzaring, J.; Fangmeier, A. Effects of atmospheric $\mathrm{CO}_{2}$ enrichment on biomass, yield, and low molecular weight metabolites in wheat grain. J. Cereal Sci. 2010, 52, 215-220. [CrossRef]

35. Högy, P.; Fangmeier, A. Effects of elevated atmospheric $\mathrm{CO}_{2}$ on grain quality of wheat. J. Cereal Sci. 2008, 48, 580-591. [CrossRef]

36. Ainsworth, E.A.; Davey, P.A.; Bernacchi, C.J.; Dermody, O.C.; Heaton, E.A.; Moore, D.J.; Long, S.P. A meta-analysis of elevated $\mathrm{CO}_{2}$ effects on soybean (Glycine max) physiology, growth, and yield. Glob. Chang. Biol. 2002, 8, 695-709. [CrossRef]

37. Brouder, S.M.; Volenec, J.J. Impact of climate change on crop nutrient and water use efficiencies. Physiol. Plant. 2008, 133, 705-724. [CrossRef] [PubMed]

38. Robredo, A.; Pérez-López, U.; Miranda-Apodaca, J.M.; Lacuesta, A.; Mena-Petite, A.; Muñoz-Rueda, A. Elevated CO $\mathrm{CO}_{2}$ reduces the drought effect on nitrogen metabolism in barley plants during drought and subsequent recovery. Environ. Exp. Bot. 2011, 71, 399-408. [CrossRef]

39. Wu, D.X.; Wang, G.X.; Bai, Y.F.J.; Liao, X.; Ren, H.X. Response of growth and water use efficiency of spring wheat to whole season $\mathrm{CO}_{2}$ enrichment and drought. Acta Bot. Sin. 2002, 44, 1477-1483.

40. Wallace, J.S. Increasing agricultural water use efficiency to meet future food production. Agric. Ecosyst. Environ. 2000, 82, 105-119. [CrossRef] 
41. Franzaring, J.; Holz, I.; Fangmeier, A. Responses of old and modern cereals to $\mathrm{CO}_{2}$-fertilisation. Crop Pasture Sci. 2013, 64, 943-956. [CrossRef]

42. Plessl, M.; Heller, W.; Payer, H.D.; Elstner, E.F.; Habermeyer, J.; Heiser, I. Growth parameters and resistance against Drechslera teres of spring barley (Hordeum vulgare L. cv. Scarlett) grown at elevated ozone and carbon dioxide concentrations. Plant Biol. 2005, 7, 694-705. [CrossRef] [PubMed]

43. Ziska, L.H.; Namuco, O.; Moya, T.; Quilang, J. Growth and yield response of field-grown tropical rice to increasing carbon dioxide and air temperature. Agron. J. 1997, 89, 45-53. [CrossRef]

44. Ziska, L.H.; Bunce, J.A. Sensitivity of field-grown soybean to future atmospheric $\mathrm{CO}_{2}$ : Selection for improved productivity in the 21st century. Funct. Plant Biol. 2000, 27, 979-984. [CrossRef]

45. Manderscheid, R.; Erbs, M.; Weigel, H.J. Interactive effects of free-air $\mathrm{CO}_{2}$ enrichment and drought stress on maize growth. Eur. J. Agron. 2014, 52, 11-21. [CrossRef]

46. Pérez-López, U.; Miranda-Apodaca, J.; Mena-Petite, A.; Muñoz-Rueda, A. Barley Growth and Its Underlying Components are Affected by Elevated $\mathrm{CO}_{2}$ and Salt Concentration. J. Plant Growth Regul. 2013, 32, 732-744. [CrossRef]

47. Poorter, H.; Navas, M.L. Plant growth and competition at elevated $\mathrm{CO}_{2}$ : On winners, losers and functional groups. New Phytologist. 2003, 157, 175-198. [CrossRef] [PubMed]

48. Ingvordsen, C.H.; Backes, G.; Lyngkjær, M.F.; Peltonen-Sainio, P.; Jensen, J.D.; Jalli, M.; Jørgensen, R.B. Significant decrease in yield under future climate conditions: Stability and production of 138 spring barley accessions. Eur. J. Agron. 2015, 63, 105-113. [CrossRef]

49. Leakey, A.D.B.; Bishop, K.A.; Ainsworth, E.A. A multi-biome gap in understanding of crop and ecosystem responses to elevated $\mathrm{CO}_{2}$. Curr. Opin. Plant Biol. 2012, 15, 228-236. [CrossRef]

50. Tausz, M.; Tausz-Posch, S.; Norton, R.M.; Fitzgerald, G.J.; Nicolas, M.E.; Seneweera, S. Understanding crop physiology to select breeding targets and improve crop management under increasing atmospheric $\mathrm{CO}_{2}$ concentrations. Environ. Exp. Bot. 2013, 88, 71-80. [CrossRef]

51. R Core Team. R: A Language and Environment for Statistical Computing; R Foundation for Statistical Computing: Vienna, Austria, 2019. 